\title{
Vital Signs End Date Time
}

National Cancer Institute

\section{Source}

National Cancer Institute. Vital Signs End Date Time. NCI Thesaurus. Code C119947.

The date and time a vital signs assessment has concluded 